\title{
The Handmade Landscape: Manual Labor and the Construction of Eden in Dickens's Martin Chuzzlewit
}

Caroline Wilkinson

University of Tennessee,

Knoxville

\begin{abstract}
In his 1843 novel, Martin Chuzzlewit, Dickens used the pastoral mode to deliver a strong message about labor. To communicate this message, he employed the mode's many traits, including its retreat into and return from the rural landscape and its focus on the country worker, traditionally the shepherd. This essay follows the novel's pastoral retreat into the United States, where young Martin comes to understand the realities of manual labor through his physical interactions with the American landscape. His companion, Mark Tapley, meanwhile, performs the emotional labor of the servant by initially shielding middle-class Martin from this painful knowledge. Both men, however, must confront manual labor on a massive scale upon reaching "Eden," a hideous landscape that Dickens constructed referring to passages from his travelogue about his 1842 trip to the United States, American Notes. The landscape in Eden documents the decaying atmosphere of slavery as recorded in Dickens's travelogue. It also recreates for Martin the physical experience that Dickens had as a child of entering a vast, foreign world of factory work. Ultimately, Dickens's uses the pastoral to uncover a horror that usually lies beneath a beautiful surface: that the civilized landscape demands enslaved or nearly enslaved labor for its construction.
\end{abstract}

\section{KEYWORDS}

pastoral, emotional labor, servants, American slavery, cotton industry

The pastoral mode makes an obvious appearance in Dickens's I843 novel, Martin Chuzzlewit. It also helps deliver a message about labor. Dickens 
conveys this message through his rhetorical use of the pastoral's many traits and not just its best-known one: its vision of nature as regenerative and pure. Retreating into nature for renewal is an essential trait of the pastoral - and so is returning to the original urban location to offer knowledge to the waiting audience (Gifford 8I-82). So Dickens not only has two Englishmen move onto an American land named Eden in search of spiritual and material renewal; he has them return from an unexpectedly harsh America with the knowledge that escaping into pastoral dreams can prove dangerous. But Dickens provides even more wisdom through his use of yet another trait of the pastoral: its focus on the rural worker. Pastoral landscapes, which, until the early I6oos, centered on the shepherd (Gifford I), are not just rural ones; they are "those of which the human centers are herdsmen or their equivalents" (Alpers 28). One such equivalent in the English pastoral is the farmer, for whom Dickens politically advocated in the 1840 s through his poetry and fiction. ${ }^{1}$ In Martin Chuzzlewit, Dickens consistently places human figures at the center of his rural landscapes, from farmers in England to enslaved, indentured, and imprisoned laborers in America. Ultimately, he uses the pastoral mode to uncover a horror that usually lies beneath a beautiful surface: that the civilized landscape demands enslaved or nearly enslaved labor for its construction.

Labor is an essential motivation for young Martin and Mark Tapley's trip to the United States, a fact that critics do not consider when examining this journey as a function of the pastoral. Recent criticism on the mode in Martin Chuzzlewit focuses less on the novel's central movement through the United States and more on smaller sections or passages, such as the scenes in London with Tom Pinch and Ruth (Edgecombe, "Urban") or the bucolic description of the Wiltshire countryside (Berard I2I). In contrast, earlier critics, Stuart Curran and Steven Marcus, analyze the American journey as a pastoral movement-Curran with a focus on biblical Edenic imagery, Marcus with a singular interest in the knowledge gained by the urban reader. Neither, however, addresses the central role that labor plays. Young Martin and Mark do not just leave England in search of paradise-or as Rodney Stenning Edgecombe asserts about Martin alone "in the hope of finding Eden" ("Urban" 370). They leave to find work, Martin as an architect and Mark possibly as a gravedigger who can remain cheerful in spite of his grim occupation. The dissatisfaction that prompts the men's journey into the United States may be idealistic in spirit, but it is earthly in focus: the men are seeking employment.

This essay will follow Martin and Mark's retreat into and return from Eden where the rural laborer emerges as a more visible figure and where the Englishmen gain a new knowledge of work. Middle-class Martin, an architect, must learn of the effort that goes into constructing not only the 
buildings on an architect's plans but the stable landscapes on which such structures rest. Working-class Mark Tapley, meanwhile, performing the emotional labor of a servant, initially protects Martin from this knowledge but eventually fails in Eden where the amount of work required overwhelms the individual will. What causes endless work in Eden is not only a lack of basic infrastructure but the land's unruly nature. This unruliness is expressed through images of rising dead matter, burial, and exhumation with "vile and ugly things" (325) threatening to rise on the muddy land. Eden is nothing but a swampy property being sold in parcels in an investment scheme to those who have not seen the desolate place. Its images of rising decay also appear on the American landscape in Dickens's I842 travelogue about his journey through the United States, American Notes. In this nonfictional account, Dickens depicts the US landscape as metaphorically exposing buried, decomposing bodies. He, for instance, speaks of a prisoner as being figuratively buried alive and then "dug out in the slow round of years" in a deteriorated state (II3). He similarly describes dead trees as dry skeletons and drowned figures that rise up to drag down the living with their branching arms (I78). In fictional Eden, the vile matter that refuses to break down causes more work, including the burials of bodies whose illness, rising into the air, causes more burials. Dickens made a similar association between burial, rot, and morals in his personal correspondence. The context in which the association appears suggests that the American landscape brought up unpleasant memories for the English novelist. The "vile and ugly things" that threaten to rise in Eden are gleaned in an I846 letter in which Dickens asserts to a friend that he let "all bad things" die and rot from his memory (4:642).

The land in Eden, by threatening to push up such things, refuses to hide the past and let it disintegrate. With its massive need of manual labor, it mirrors a setting that Dickens often recalled: the blacking factory where he began working as an eleven-year-old. ${ }^{2}$ As I will show, young Martin's move onto his forested parcel in America mirrors Dickens's entrance into the foreign world of factory work. Just as Dickens as an adolescent had to abandon his dreams of getting an education to label bottles in a blacking factory, young Martin must put down his draftsman's pencil in favor of an axe. While David Copperfield is widely seen as Dickens's most autobiographical novel, ${ }^{3}$ Martin Chuzzlewit may be the one most influenced by what Rosemarie Bodenheimer refers to as the "unwilled, negatively inflected reflections" that kept returning to shape Dickens's fiction (Knowing 57). In the decay of Eden, Martin is shocked, just as Dickens at eleven was, by the discrepancy between his plans for the future and the work surrounding him in the 
present. Dickens recreates an eleven-year-old's perception of confronting factory work by depicting labor on an immense scale. This work includes digging drainage systems, clearing forests, and building levees, all work that, in I840s America, was being performed by the enslaved, indentured, imprisoned, and extremely impoverished.

The English countryside where Martin and Mark enter the novel seems naturally beautiful. It almost erases the embodied workers who helped create the landscape and who maintain its cultivated splendor. At the beginning of chapter 2, Dickens describes a part of Wiltshire where Mark works at the inn and ale house, the Blue Dragon, and where Martin will come to apprentice with the architect, Pecksniff. The description begins with an autumn scene that initially characterizes nature as regenerative. The sun brightens "[1]ike a sudden flash of memory or spirit kindling up the mind of an old man" (6). This pastoral vision of nature does not fully include all residents in Wiltshire where laborers historically have been exploited. Jane Berard suggests these workers have even been enslaved (74). She documents how, in the late I830s, laborers in Wiltshire were organizing Chartist meetings and taking up arms (74). Their deprivation, which Dickens wrote of in his 1846 poem, "The Hymn of the Wiltshire Laborers," is not literally shown in Martin Chuzzlewit's chapter 2. Berard, who characterizes this scene as "pseudo-pastoral" (I2I), argues that while the description seems calm and beautiful, the plight and rage of the laborers is represented through the wind-blown, combustible foliage when the scene grows dark. ${ }^{4}$ The farmer himself is not seen in the flesh at first, not even when his work comes into view. The scattering of the seed "hither and thither" precedes any mention of the man who is affecting this action with his hands, making his efforts seem to arise out of the lovely afternoon itself, this effort being in "gentle unison" with the scene's repose (6). Not until night has fallen and the man starts to exit the landscape can the reader see his body heavy with work: "the labourer unyoked his horses, and with head bent down, trudged briskly home beside them" (7). When visible at last in the dark, he resembles the animals next to him.

Rather than viewing Dickens's depiction of this land that Mark and Martin soon leave as pseudopastoral, one could see it as a sincere use of the mode that shows, by not showing, how the English pastoral had come to obscure the laborer whose body was becoming a site of socially constructed, seemingly unnatural fear. Dickens had already demonstrated a genuine interest in the pastoral's traditional central figure in his I836 play, The Village Coquettes, which opens with workers unloading corn-sheaves from a cart while singing of the harvest (45). In Wiltshire, the human 
center has become not recognizably human: he resembles a workhorse when he becomes visible in the dark. When the sun is shining and seeds still being sewn, his hands specifically are hidden from view. Dickens's erasure of this extremity seems to contribute to the beauty of the bucolic scene when viewed in light of then-emerging beliefs about the hands of manual laborers. As Peter Capuano documents, working-class hands by the late I85os were widely seen as animalistic with nonhuman features, including short fingers and large palms, which made them naturally good for wielding large tools (136-37). While Martin Chuzzlewit appeared in the decade prior to the documented acceptance of such beliefs, the attitudes expressed by the characters in the novel about manual labor include fear and dread. Martin, after leaving his apprenticeship with Pecksniff, speaks of the unemployment that will drive him from England, saying to the woman he loves, Mary: "have I thought of doing porter's work for a living; have I thought of holding horses in the streets to earn my roll of bread from day to day?" (204). This question rhetorically acts as an expression of his plight. While any working-class position would be a downward move for Martin, it is worth noting that the manual jobs mentioned here elicit such dread that the subject is not discussed further by him and Mary. Given that work associated with the hands could elicit shocked silence in middle-class conversation-and that such labor was on the verge of being associated with animalistic traits-Dickens's erasure of the farmer's hands could have been a necessary omission in a scene written in a mode associated with beauty and requiring a human center.

When Martin and Mark retreat to the United States to find their desired work, they discover a country that cannot hide anything behind either a literary history or well-constructed landscape. In contrast to Wiltshire, which is home to ancient sites including Stonehenge, the first city Mark and Martin see, New York, is obviously new and unformed. When the men prepare to disembark, a hawker's voice repeatedly shouts "The Sewer," a structure that should stay below the feet. While "The Sewer" turns out to be a newspaper that exposes scandal, its name and the purpose of the paper set the tone for Mark and Martin's American experiences. The men encounter more exposure of the private realm on shore where immigrants gather with their belongings. Their beds have "the bare ground below them and the bare sky above" (224). The scene dramatically contrasts with the English urban landscape left behind, which, as Steven Connor notes, is made of "built spaces" (emphasis in original 185) around the London boardinghouse, Todger's. Below the immigrants' beds in the United States is bare ground, while below Todger's are foundations that include horse stables 
and inspiration for fictional tales. About these foundations, the narrator tells us: "cart-horses, troubled by rats, might be heard on a quiet Sunday rattling their halters, as disturbed spirits in tales of haunted houses are said to clank their chains" (II4). The United States did not have as many shared tales yet, a fact that Edgecombe speculates bothered Dickens during the novelist's I842 American trip; Dickens seemed to prefer landscapes along the Hudson River, which had been "written into human consciousness" by Washington Irving with his stories (Edgecombe, "Topology" 48). One literary mode that had written America into consciousness was from Europe, the pastoral, as Leo Marx argues in his landmark study of the mode's influence on nineteenth-century American literature. Dickens, employing this mode, has his Englishmen move farther into this country where everyone, including laborers, is more exposed.

When, however, Mark and Martin later encounter a person who has performed the hardest tasks in the United States, the ex-slave Cicero, Martin is saved from confronting the man's horrendously abused body by Mark's emotional labor. Cicero, who has suffered a shooting, a galling with an iron collar, gashings, beatings, and other violence, never speaks to Martin or anyone else within the novel's present-tense narrative. John Bowen argues that Dickens tells the story of slavery through Cicero's silence, asserting that the scarred body says a great deal on its own (205); but, significantly, Martin does not perceive the story of this body's abuse directly through the visible scars. Rather, the story is narrated by Mark, who, being in service, is closer in class to Cicero. The ex-slave now works as a porter, a job that does not horrify Mark, whose peculiar ambition is to challenge his own good cheer through a job as grim as grave-digging. Mark, when speaking of these ambitions, exposes a gap between the public emotions he affects at the Blue Dragon and his own private feelings, a separation that Arlie Hochschild identifies in her foundational study of service workers who, as part of their job, must create an upbeat atmosphere through performances of happiness. While Mark is largely responsible for the merriment at the Blue Dragon-a fact of which Tom Pinch reminds him and which he himself acknowledges (6I)he feels aggravated and looks "particularly gloomy" (60) when he speaks of how his jolliness is easy to maintain, given that the atmosphere at his work is jolly. Even though he admits to a familiarity with difficult patrons when he remarks that waiting on the nefarious Tigg and Slyme would be better than grave-digging and identifies old Martin as a "trying customer" (99), he views his job as effortless because of the fun atmosphere he himself creates. His logic allows him to be as unaware of his own emotional labor as Martin is of the work of others. Mark ends his account of Cicero's story with manic 
cheer strained by irony, "Liberty for ever! Hurrah!" He is referring to Cicero purchasing his own freedom after the man's body becomes so damaged that the price goes down sufficiently. Martin never has to see Cicero's injuries, which, Mark says, are so horrible they cause a loss of appetite (242). Martin only hears the story of slavery as told through the visibly abused body without experiencing it with an immediacy that could sicken.

Martin's understanding of slavery, as mediated by Mark, is extremely limited, a fact that becomes apparent later when Martin fails to see how much work it would take to build the city of Eden from the ground up. When he learns that the civic buildings that appear in the promotional architectural drawings for the "city" exist solely on paper, he is not worried about the manual labor their construction would demand. His extreme naiveté about such labor is not shared by Mark Tapley, who remarks to the salesman, Scadder, after learning that the impressive array of civic buildings has not been constructed: "The soil being very fruitful, public buildings grows spontaneous perhaps" (307). This remark heralds a line that Dickens would write in A Child's History of England about the Druids' use of commoners' labor in the construction of Stonehenge: "I should not wonder if the Druids, and their pupils who stayed with them twenty years, knowing more than the rest of the Britons, kept the people out of sight while they made these buildings, and then pretended that they built them by magic" (I32). America believed in Christianity rather than the Druids' magic and, therefore, its buildings, after being constructed by "people out of sight," could been seen as springing up from Eden's "fruitful" soil. Mark quickly backtracks after making his statement and ends up paying for a parcel without Martin's financial help. His knowledge of labor before entering Eden seems to be a source of shame when he thinks that he, with his remark about fruitful soil, has been "putting his foot in it already" (307). Christianity's Eden is a place where shameful knowledge means exile, and so Mark hides his understanding of labor and goes along with Martin, who remains innocent of the scam.

Martin departs for Eden in a scene that underscores his innocence through its withholding of essential knowledge: neither the reader nor Martin knows why he must shake countless hands before leaving for his purchased parcel. This hand-shaking scene has been criticized for being too obvious an insertion of autobiography on the part of Dickens, who had to greet people at a high volume during his 1842 trip to the United States, shaking hands with, for instance, 500 strangers at one time in Philadelphia (Letters 4:443n7). Robert Lougy defends the novel's scene from one of its main criticisms: that it is too improbable of an event within the fictional narrative, which has the crowd shaking Martin's hand because no one 
ever comes back from Eden alive. The motivation that Dickens invented for the crowd makes the swarming mass of hands almost otherworldly in its inquisitive cruelty. Lougy argues that this depiction of the crowd works with Dickens's overall characterization of America's attitude toward the two Englishman, asserting that the aggression toward Mark and Martin in this farewell is present throughout the novel's US scenes (578). Certainly, Dickens shows America as viscerally hostile from the moment the two Englishmen hear a voice hawking The Sewer. But it is notable that only Martin, who does not grasp Eden's scam, is introduced to the crowd for this handshake, which seals a bad deal for him. It also truly welcomes him to a markedly religious country whose faith primarily underscores the shamefulness of knowledge in its creation myth but whose predatory capitalism forces citizens to become knowledgeable and remain vigilant so that they can avoid possible scams.

As Martin and Mark move toward Eden, the descriptive passages of the landscape begin to repeat descriptive passages of landscapes from American Notes. The journey into Eden initially evokes a "monotonous desolation" that brings Martin and Mark into hopelessness made flesh: "they might have entered, in the body, on the grim domains of Giant Despair" (325). An American, General Choke, calls his country "primeval" (299) when speaking of Eden to Martin, and the landscape indeed causes the reader to go back to a time when nothing was constructed; when at first no buildings appear along the muddy riverbanks. For those who have read American Notes, the landscape soon looks familiar. Mark and Martin see ash, a marsh, fallen logs-all details that appear on the land in American Notes. When this burned and rotting matter comes into view in Dickens's travelogue, it transports him back in time. He first sees it while travelling by train from Boston to Lowell: "When Whir-r-r-r! almost before you have seen them, comes the same dark screen: the stunted trees, the stumps, the logs, the stagnant water-all so like the last that you seem to have been transported back again by magic" (74). In Martin Chuzzlewit, Dickens takes the raw material of this moment of repeating and returning and uses it to create a crude landscape. Harry Stone in his frequently cited article on Dickens's use of autobiography in Martin Chuzzlewit mentions this particular repetition of rotted matter near Lowell. Stone criticizes Dickens for focusing on the decay in America at the expense of beautiful aspects of the landscape (467-68); but Dickens, by repeating such decay-and, at the same time, what does not decay in his own memory of the United States-is creating a monotonous landscape whose human activity arises from its perpetual rot. The hands that send Martin to this land repeat just as the same stumps 
and swamps repeat. Dickens describes the hands at Martin's sendoff using a grammar that underscores sameness in the midst of apparent variety, giving a list of adjectival nouns, "the hot, the cold, the dry, the moist" (316). In American Notes, Dickens creates variation in his own mind while staring at the repetitive decay. He writes of the stumps: "The varying illusions they present to the unaccustomed eye as it grows dark, are quite astonishing in their number and reality" (216). What astonishes is that these stumps exist again and again. Dickens's own imagination must supply any difference by moving further back into his own memory: "and strange to say, I sometimes recognized in them, counterparts of figures once familiar to me in pictures attached to childish books, forgotten long ago" (215). The strangeness brings about a familiarity long lost to the conscious mind.

Mark and Martin only arrive at their parcel after moving through a repetition that overtly - and, I will argue, strategically - uses American Notes as raw material for the landscape. Dickens disrupts the novel's fictional world by drawing upon his previous published observations of the United States. For those who have read American Notes, the repetition is obvious; and for all readers, the use of factual observations to create a fictional land could strain the world of Martin Chuzzlewit. The insertions lead to the novel's jarring contrast between a muck-filled America and a bucolic Wiltshire. Within this realist novel, both landscapes exist, one choked with horrifying matter, the other light with breezes. In arguing that the reappearance of descriptions from American Notes in Eden strains the fiction, I am agreeing with Harry Stone's overall criticism that Dickens's use of autobiography in Martin Chuzzlewit can undermine the fictional world's integrity-but I am making this distinction: I see the disruption of the fiction of Eden's landscape as a strategy for bringing into the novel a nonfictional truth of a damaged terrain.

The damage named in this repeating passage-swamps coupled with deforestation-specifically resulted from practices used by the cotton industry along the Mississippi. As historian Walter Johnson explains, the Mississippi was essential to the transportation of cotton, which travelled to domestic manufactures and also to a foreign one: eighty-five to ninety percent of the crop travelled to Liverpool with America supplying around eighty percent of England's cotton (Io). The Mississippi, being straightened, dredged, and leveed for industry, ran faster and overtopped its levees, which, in turn, prevented the water's return to the riverbed-"[o]r to put this differently," Johnson adds, "levees created swamps" (90). Nick Yablon notes that when Dickens visited the town of Cairo, Illinois, which rests at the confluence of the Ohio and Mississippi Rivers and on which Eden is widely 
thought to be based, a flood had recently breached "jerry-built levees" and, after receding, left swamps (63). The stumps in Dickens's description of rot, furthermore, speak of the fuel demands of steam engines of the boats that transported cotton. Dickens, through his references to his own observations of swamps and stumps, is creating a disturbingly real landscape damaged by industry in general and the slavery-dependent one of cotton specifically. ${ }^{5}$ Dickens in using American Notes as raw material makes a landscape out of his own observation of industrial damage caused by the production of an American raw material, cotton.

Young Martin cannot conquer this landscape of stumps and stagnancy that Dickens brings into his fictional Eden. Cairo, Illinois resembles this Eden in that it was presented as an investment opportunity that resulted in financial loss. This presentation was made by wealthy speculator Darius Holbrook, the president of the Cairo City and Canal Company, who used a set of architectural plans to sell bonds in the city (Russell 204). These drawings were completed by William Strickland, who was well regarded for his skill as a draftsman (Russell I95, I99). Dickens gave this skill to young Martin, who gains attention for the architectural plans he draws for a school. Strickland's plans for Cairo were as elaborate as those that Scadder uses to market Eden; they included a courthouse, factories, a church, a building with a triple-gabled roof, and an obelisk-shaped monument (Russell 20I-3). On Strickland's drawings, which were never realized, levees surrounded the city, and, in Martin Chuzzlewit, Eden clearly is in dire need of protection from the river it abuts. Dickens underscores young Martin's ineffectualness upon the architect's arrival in Eden by having him hang a business sign. This sign advertises Martin's profession in a place that has neither many paying customers nor able-bodied builders, a large number of the residents being ill. The discrepancy between Martin's present reality and plans for the future mirrors those of Dickens upon his father's imprisonment for debt, at which point Dickens had plans of attending Cambridge, even though no one in his family had gone to university (Tomalin 24). Young Martin, who thinks of the job of porter as beneath him, sits under a sign that announces the absurdity of his self-image. In Eden, not only must he carry his own bags after asking for help, he learns that he may have to dig graves soon enough when his neighbor remarks "as an additional scrap of local chit-chat" that he dug the last proprietor's grave (326). The naiveté that Mark Tapley has helped sustain about how cities are built looks absurd under the architect's sign.

Mark Tapley, meanwhile, upon his arrival, takes up a hatchet, but the tasks he faces are so immense they overwhelm the individual will. Mark's chopping is futile, making him appear with his axe, the narration tells us, "intent on performing some impossibilities with that implement" (329). 
The barriers he confronts are not the kind that an Englishman can overcome with willful optimism and hard work, unlike the challenges presented in Dickens's novel six years later, David Copperfield, in which the hero claims to clear "forests of difficulty" with his "woodman's axe in hand" (505). Mark lacks the skills, knowledge, and strength of those people whose wills went legally unrecognized along the Mississippi when Dickens visited: the slaves who cleared the banks of the river. The forest by the Mississippi could be cleared at a rate of an eighth of an acre a day by a "full hand" or productive slave, a "half hand" being a less efficient slave, such as a nursing mother (W. Johnson 154). In Eden, Mark's enthusiasm about work looks as absurd as Martin's ignorance of it.

The nature of this uncompleted work, along with the references to American Notes, reintroduces slavery to the landscape to create a fatal reality. Eden is deathly, inflicting its residents with fever. In Martin Chuzzlewit, Dickens refers not only to his firsthand observations of the United States from American Notes but to his secondhand ones as well. Just as young Martin does with Cicero's story, Dickens took in information about slavery secondhand during his trip. ${ }^{6}$ In his chapter in American Notes dedicated to the subject, he exclusively cites advertisements printed for the capture of slaves. He repeats physical wounds listed in the ads, which name punchedout teeth, amputations, and other disfiguring and possibly fatal injuries to identify the given person who has fled enslavement. In their severity and variety, these injuries resemble Cicero's. The enslaved body is not literally present in Eden, which is situated in an unnamed location that could be either in a slave state or a free one, although, with no currently enslaved people represented, the latter is indicated. The landscape that Dickens constructs in Eden ultimately destroys the individual. The "vile and ugly things" that threaten to rise turn into a single "noxious vapour" (456), while the single death - that subject of local chitchat-becomes a shared demise. The narrator says after Martin falls deathly ill: "The season was a sickly one; the settlement a grave" (445). Sean Purchase argues that slavery finds articulation in Martin Chuzzlewit through illness, the "disease of slavery" entering Mark's and Martin's flesh and incubating within it (I2). I would agree but propose that it may not incubate over the course of the journey as much as rise from the landscape in Eden through a deathly vapor that comes out of what will not decompose and what operates as nonfictional raw material in this American pastoral.

Mark and Martin, as they continue on in Eden, lose their hope of escape without surrendering it entirely, much as Dickens did at the blacking factory. They speak of home and the people they remember there with vacillating 
expectations of ever returning, "sometimes in the lively hope of seeing them, and sometimes with a sorrowful tranquility, as if that hope were dead" (454). Dickens too experienced a profound loss of hope in the factory without ever fully surrendering it, writing in 1848 in the "Autobiographical Fragment": "My rescue from this kind of existence I considered quite hopeless, and abandoned as such, altogether; though I am convinced that I never, for one hour, was reconciled to it" (Forster I:53). The seemingly total loss of hope coupled with its endurance in Martin Chuzzlewit and the factory cannot be separated from the fact that, in both situations, work is everywhere but completing it is impossible and trying to do so will not change one's situation. In both Eden and the factory, rescue is required.

At the human center of the US landscape emerges a much more visible husbandman than the one in Wiltshire-depressingly so, given that this laboring body is sick and also metaphorically imprisoned. The individual husbandman reappears in the United States as part of a deluded group, having wandered into the settlement "with the idea that husbandry was the natural gift of mankind" (454). This figure labors with others like him as they together work "as hopelessly and sadly as a gang of convicts in a penal settlement" (454). Dickens remarks in American Notes that the United States does not share England's "prejudice against prison labour" (6o). Prisoners, like slaves, were used for manual labor in large projects in the United States, employing skills that the metaphorically imprisoned residents of Eden with its need of drainage could possibly use. Prisoners, for instance, helped construct the Patowmack Canal, working alongside Irish immigrants, whose indentures the canal company bought, and slaves also purchased by the company (Bernstein 74). Many laborers tried to flee "the horrors of the work" (Bernstein 269) but were captured and brought back. Mark and Martin can only gain their freedom when they get some money. Dickens underscores the stark connection between money and freedom in how he has the necessary funds arrive. The Englishmen receive an envelope that contains no words at all, only cash. Dickens similarly gained his freedom from the factory when the owner received a letter whose words Dickens never saw. The letter, written by his father, left Dickens speculating about its contents. Eden inspires a wordlessness that specifically affects freedom as defined by the American character, Chollop. While Chollop usually expresses a great devotion to his country's liberty, along with its slavery and Lynch law, he refrains from bragging about America's freedom in Eden, which he, unlike the other residents, is about to depart. The narration parenthetically adds about this uncharacteristic restraint: "(for the genuine Freedom is dumb, save when she vaunts herself)" (448). American Freedom 
will not speak when bragging would be absurd and rude and, furthermore, would force Chollop to see that one of his essential values is false.

The way in which Mark and Martin gain this money yields the knowledge that this pastoral overtly offers its audience. It also underscores that the Englishmen are not slaves. The money that Mark and Martin receive results from a letter written to an American friend whose response of cash, in turn, prompts the narrator to state: "Smart citizens grow rich, and friendless victims smart and die, and are forgotten. That is all" (456). This knowledge is not relevant to the enslaved whose friendships have no bearing on their inability to leave the land on which they work. A slave, furthermore, even if he or she could read and write, would not have had Mark and Martin's unselfconscious access to the postal service. Literacy among slaves was widely illegal, and, even when this law was broken with a successfully mailed letter, postmasters often interfered with the delivery (Schiller 26, 28n.), as did slave owners (Hager 75). Within Martin Chuzzlewit, Cicero silently stands outside of this epigrammatic line, his injuries so far exceeding the pain of a "smart" that they fall beyond the reach of ironic understatement. These friendless victims are not slaves, and neither are they smart citizens. Whether they are citizens at all is unclear in the epigrammatic line. It is certain, though, that one kind of citizen on this landscape, the Scadders, wields a "smart" that wounds with its double edge. Intelligence among these particular citizens is about acquiring money, not wisdom. The knowledge that this pastoral has to offer, therefore, is not relevant to them. It is, however, relevant to the waiting audience in England wanting to know about this landscape, especially those who are considering visiting or emigrating to the United States. It serves as a warning about America's predatory citizens and the danger of being in an unfamiliar country without friends. ${ }^{7}$

Further knowledge, however, some of it "dumb" in the sole sense that the word is used in the novel (Dickens does not employ its then-emerging meaning of unintelligent), is offered after Mark and Martin's trip back to England, which resembles Dickens's return home from the factory. The left-behind locale becomes like a dream with Mark and Martin remembering Eden in their sleep. The narrator writes of their dreamt memories of those riverbanks: "How often was it happiness to wake, and find them Shadows that had vanished!" (456). Dickens similarly remembered the factory frequently in his sleep, writing in the "Fragment": "I often forget in my dreams that I have a dear wife and children; even that I am a man; and wander desolately back to that time of my life" (Forster I:53). That time revisited in dreams causes a loss of words. Dickens writes that, on the subject of the factory, his parents "have been stricken dumb" (Forster i:69). Martin 
Chuzzlewit may not have been critically considered as particularly autobiographical in regard to the blacking-factory experience because the part of the memory it expresses centers on silence. It speaks of no one being able to talk about a foreign place. "Dumb-ague," an American word for a bilious fever that can strike a single town and be "exceedingly fatal," has its first recorded use in 1832 in View Valley of Mississippi (OED). This illness is like the one that rises from the ground in this American pastoral in which a near-fatal fever brings Martin and Mark closer. The two men, when they fall sick, care for each other with an affection that defies their class difference and that Mark Twain would also find at the center of the same landscape in I884. Along the Mississippi, Twain brought Huck and Jim closer together as they travelled toward Cairo in spite of their separation within a racial caste system. ${ }^{8}$ Once Mark and Martin leave America, their close affection formed on the US landscape disappears. The lessons that Martin and Mark learn in Eden-a place the narration calls a "hard school" (452)-center on loss. Martin learns upon his return that his architectural plans for the school have been stolen by Pecksniff, while Mark loses all credit for being cheerful in dismal circumstances. He takes the action that "has the least credit in it of all" (629), as he tells Tom Pinch about his decision to marry the woman he loves, Mrs. Lupin. Eden causes a loss of credit, but, as the hard school dissipates in the light of the landscape, English class relationships are recovered with Mark and Martin becoming distant again. Martin goes on to regain his inheritance, thereby securing his social position.

The return from America also offers silent knowledge to its audience through Edenic pastoral imagery as analyzed by Stuart Curran, who asserts that such links are structurally essential to this sprawling novel. ${ }^{9}$ The American section, for instance, is clearly connected to the English scenes through references to a biblical paradise that appear in both countries, with America's Eden being connected to England's Pecksniff, who refers to himself as Adam. While I agree that such imagery helps cohere the novel, I believe that an analysis of the narrative's overarching retreat and return reveals why Eden is a crude scam and Pecksniff can hide that he is a serpent from himself and, for almost the entire novel, society. The American landscape offers no place to hide, not even for the buried, while civilized England can obscure a husbandman in the midst of a scene of seeds being sewn.

Dickens's pastoral not only draws upon Milton and the Bible, as Curran asserts; it also refers to Dante and his guide into hell, Virgil, who forged a path for the political pastoral with his Eclogues. Fanny Trollope's I832 travelogue, Domestic Manners of the Americans, which Dickens read prior to his US trip, opens with a comparison between the entrance to the Mississippi 
and Dante's Inferno. The first eclogue by Virgil is centered on a shepherd who loses his land when the state boards soldiers on his property. Dickens followed this politicized tradition of the pastoral when he travelled to the US whose third constitutional amendment, largely forgotten but known in I842, limits the government's right to board soldiers on a citizen's property. The United States cast off England's rule to gain a freedom that Dickens critiques in Eden. Sickening and depressing, the atmosphere in Eden is not unlike that of Richmond, Virginia as described in American Notes. Dickens testified to the "decay and gloom" (I53) above the city and elsewhere in Virginia when he wrote of its "air of ruin and decay" as being "inseparable from the system [of slavery]" (I5I). ${ }^{10}$ Outside of his description of the landscape between Boston and Lowell, Dickens uses the word "decay" only three other times in American Notes, and two of these three are in reference to the air in the slave state of Virginia. The hell that Dickens creates draws on religious imagery, but it also speaks of social realities. It does so silently through textual repetition and loudly through the English characters' overt criticism of slavery.

America's landscape remains linked to England's in Martin Chuzzlewit, even after it vanishes into a dream, in two final ways: the primeval United States is an earlier version of a more developed England, and it is also a present-tense supplier of cotton for the older country. When viewed from either of these perspectives, the American landscape shows through what it exposes as a reoccurring dream, a lesson of loss, and a hell that the civilized landscape requires enslaved and nearly enslaved labor for its construction. It reveals the poor conditions of past forgotten workers who were hidden away to build Stonehenge and other grand structures; and it shows too the brutalized slave who makes the raw material to dress English figures in civilized nineteenth-century pastorals. Dickens suggests through young Martin's narrative that such extreme exploitation arises out of the inability of those who draw such large-scale plans to see the realities of labor. He also shows the difficulty in remedying this problem. The failure of perception is clearly not a simple matter of geography. Servants in England also protect the middle- and upper-classes from bearing witness to the exploitation of other workers. Dickens, furthermore, shows how the emotional labor of the servant is, like Pecksniff's desire for money, hidden from the self and, therefore, difficult in the extreme to self-regulate. Finally, Dickens demonstrates through Mark and Martin's narrative that, even when the realities of manual labor are confronted, they can be easily forgotten when no longer immediately present. The brutal knowledge that Dickens conveys in this pastoral, while relevant to the urban audience, is hard to recall after Mark 
and Martin's return. The two men themselves manage to forget the affection they formed as part of the "human center" of an American landscape. They forget, too, Cicero, their fevers, and America's Freedom, except in dreams, as they move into plots about marriage and inheritance.

CAROLINE WILKINSON is a Post-Doctoral Lecturer at University of Tennessee where she received her Ph.D. in English, Creative-Writing Dissertation. She earned her MFA from Washington University in Saint Louis and her BA in English from Vassar. Her essay on Kabbalistic astronomy and astrology in Daniel Deronda was published in George Eliot-George Henry Lewes Studies. Her reviews have appeared in GH-GHLS and Victoriographies.

\section{Notes}

I want to thank Dickens Universe's Winter Conference where I received helpful feedback on a paper that became part of this article. I especially would like to thank Renee Fox, who gave me a detailed critique of my conference-paper draft. Also, my gratitude to Sophie Raine and Stephen Basdeo, who organized a conference on class at Lancaster University where I gave another paper that contributed to this article.

I. Dickens expressed concern for the rural working class in the I840s in his poetry ("The Hymn of the Wiltshire Laborers") and fiction (The Chimes). In both, the farm laborer is depicted as living on the edge of starvation. Dickens wrote The Chimes, as he himself said in an 1844 letter, to make "a great blow for the poor" (4:200).

2. See Allen 94 for a discussion of this age.

3. While critics frequently see Dickens as grappling with his past throughout the I840 (see Patten, 269, 288nI), they do not characterize Martin Chuzzlewit as being markedly connected to the author's memories of factory work. A major element of the novels seen as expressing such memories is the figure of the orphaned child. This figure is often interpreted as an expression of the parental abandonment Dickens felt at the factory (see, for instance, Edgar Johnson 46.). This figure is not present in Martin Chuzzlewit, which explores selfishness and hypocrisy as perpetuated and perceived by adults.

4. Berard characterizes Dickens as essentially subverting the pastoral mode itself, a view shared by more recent critics, who also characterize the novel, either generally or in parts, as "anti-pastoral" (Edgecombe, "Urban" 370) and "counter-pastoral" (D. Johnson 236-37). Earlier critics, including Marcus, Curran, and Bodenheimer in a 1979 article, generally see the English novelist more as complicating the mode to achieve specific rhetorical goals.

5. In arguing that Dickens's use of autobiographical material is purposeful, I am following the path established by Jerome Meckier and, subsequently, Nancy Metz ("America Revised”). They view Dickens's reworking of nonfictional material in Martin Chuzzlewitthey specifically examine his intertextual conversations with other travel writers-as a strategic revision of American Notes. Meckier and Metz, however, see these revisions as a refinement of the prior writing, whereas I interpret the reappearance of parts of American Notes in Eden's landscape as a purposefully crude repetition. 
6. For an explanation of Dickens's use of secondhand sources in American Notes that also addresses the novelist's reluctance to witness slavery firsthand, see Claybaugh. The other topic for which Dickens used secondary sources, writes Claybaugh, was his visit to the Perkins Institution and Massachusetts Asylum for the Blind. In American Notes, Dickens recounts his interaction with Laura Bridgman at the institute extensively. He describes her and another child at the institution as "dumb" or unable to speak, an affliction that, as I will show, arises in Eden.

7. See Metz's "Fevered with Anxiety for Home" for an analysis of how Martin Chuzzlewit warns its readers about the dangers of emigrating to the United States.

8. The homosocial bond between two men of different racial castes notably arises in American pastoral fiction in the nineteenth century. Examples presented by Leslie Fiedler in his famous study of the novel's development in the United States include not only Huckleberry Finn with Huck and Jim but Moby Dick with Ishmael and Queequeg. Both of these novels are central to Leo Marx's examination of the American pastoral. Fiedler locates as a source for this homosocial coupling the guilt experienced by the white man over the enslavement of African people and the genocide of Native Americans. It is notable that Dickens, engaging with the mode of the pastoral in America, creates at the human center of his US landscape a coupling between two men from different strata of the English class system. It suggests that the landscape populated with slaves, laboring prisoners, and poor and indentured immigrants could bring about guilt about labor hierarchies even in visitors.

9. Curran argues against prevalent early criticism that Martin Chuzzlewit is formless. He calls Tillotson's criticism that the novel lacks a well-executed structural plan (I60-6I) a typical assessment. Curran himself calls the plot "rambling" (55).

Io. Dickens's use of "gloom" here brings to mind a passage from ex-slave Hannah Crafts's nineteenth-century novel, The Bondwoman's Narrative, which describes the American landscape using parts of Dickens's Bleak House, a novel Rae Greiner convincingly argues draws upon the pastoral mode. Crafts borrows a passage from Bleak House to characterize the air in Washington DC. Dickens's lines, "Fog everywhere. Fog up the river" (BH II), become in her description: "Gloom everywhere. Gloom up the Potomac" (Crafts I6I). Crafts's replacement of the English "fog" with American "gloom" suggests an awareness on her part of Dickens's technique of repeating texts.

\section{Works Cited}

Allen, Michael. Charles Dickens and the Blacking Factory. Ist ed. Oxford-Stockley, 201 I.

Alpers, Paul J. What Is Pastoral? U of Chicago P, 1996.

Berard, Jane Helen. Dickens and Landscape Discourse. Peter Lang, 2007.

Bernstein, Peter L. Wedding of the Waters. Norton, 2005.

Bodenheimer, Rosemarie. "Dickens and the Art of Pastoral." Centennial Review, vol. 23, I979, pp. 452-67.

- Knowing Dickens. Cornell UP, 2007

Bowen, John. Other Dickens: Pickwick to Chuzzlewit. Oxford UP, 2003.

Capuano, Peter J. Changing Hands: Industry, Evolution, and the Reconfiguration of the Victorian Body. U of Michigan P, 2015.

Claybaugh, Amanda. "Toward a New Transatlanticism: Dickens in the United States." Victorian Studies: An Interdisciplinary Journal of Social, Political, and Cultural Studies, vol. 48, no. 3, 2006, pp. 439-6o. 
Connor, Steven. "Babel Unbuilding: The Anti-Archi-Rhetoric of Martin Chuzzlewit." Dickens Reconfigured: Bodies, Desires, and Other Histories. Edited by John Schad. Manchester UP, 1996, pp. 178-99.

Crafts, Hannah, and Gates, Henry Louis. The Bondwoman's Narrative. Warner Books, 2002.

Curran, Stuart. "The Lost Paradises of Martin Chuzzlewit." Nineteenth-Century Fiction, vol. 25, no. I, I970, pp. 5I-67.

Dickens, Charles. American Notes. Edited by Patricia Ingram. Penguin, 2004.

—. Bleak House. Edited by Stephen Gill. Oxford UP, I999.

—. A Charles Dickens Christmas. Oxford UP, I976.

- Complete Plays and Selected Poems of Charles Dickens. Vision, I970.

—. David Copperfield. Edited by Nina Burgis. Oxford UP, I999.

- The Letters of Charles Dickens: I820-I870. Edited by Madeline House, et al. Clarendon P, 1965-2002. I2 vols.

—. Martin Chuzzlewit. Edited by Margaret Cardwell. Oxford UP, I982.

- Master Humphrey's Clock and A Child's History of England. Oxford UP, I998.

"dumb, adj. and n." OED Online, Oxford UP, March 20I8, www.oed.com/view/Entry/58378. Accessed 5 April 2018.

Edgecombe, Rodney Stenning. "Topographic Disaffection in Dickens's American Notes and Martin Chuzzlewit." Journal of English and Germanic Philology, vol. 93, no. I, I994, pp. 35-54.

—. "The Urban Idyll in 'Martin Chuzzlewit." The Review of English Studies, vol. 45, no. I79, I994, pp. 370-83.

Fiedler, Leslie A. Love and Death in the American Novel. Rev. ed., Stein and Day, 1966.

Forster, John. The Life of Charles Dickens. 2 vols. Dutton, 1927.

Gifford, Terry. Pastoral. Routledge, I999.

Greiner, Rae. "Bleak House: Pastoral." Critical Quarterly, vol. 55, no. I, 2013, pp. 75-93.

Hager, Christopher. Word by Word. Harvard UP, 2013.

Hochschild, Arlie Russell. The Managed Heart: Commercialization of Human Feeling. U of California P, 1983.

Johnson, Derek. Pastoral in the Work of Charles Dickens. Peter Lang, 1992.

Johnson, Edgar. Charles Dickens, His Tragedy and Triumph. Simon and Schuster, 1952.

Johnson, Walter. River of Dark Dreams. Harvard UP, I9I3.

Lougy, Robert E. "Desire and the Ideology of Violence: America in Charles Dickens's Martin Chuzzlewit." Criticism: A Quarterly for Literature and the Arts, vol. 36, no. 4, I994, pp. 569-94.

Marcus, Steven. Dickens from Pickwick to Dombey. New York, I965.

Marx, Leo. The Machine in the Garden: Technology and the Pastoral Ideal in the Novel. Oxford UP, 1964 .

Meckier, Jerome. Innocent Abroad: Charles Dickens's American Engagements. UP of Kentucky, I990.

Melville, Herman. Moby Dick. Edited by Harrison Hayford and Hershel Parker. Norton, 1967.

Metz, Nancy Aycock. "'Fevered with Anxiety for Home': Nostalgia and the 'New' Emigrant in Martin Chuzzlewit." Dickens Quarterly, vol. I8, no. 2, 200I, pp. 49-6I.

- "The Life and Adventures of Martin Chuzzlewit: Or, America Revised." Dickens, Europe and the New Worlds. Edited by Anny Sadrin. St. Martin's, I999. 
Patten, Robert L. "Autobiography into Autobiography: The Evolution of David Copperfield." Approaches to Victorian Autobiography. Edited by George P. Landow. Ohio UP, I979, pp. 269-91.

Purchase, Sean. "'Speaking of Them as a Body': Dickens, Slavery and Martin Chuzzlewit." Critical Survey, vol. I8, no. I, 2006, pp. I-I6.

Russell, Robert D. “The Planning and Failure of Cairo, Illinois I830-I840." Journal of Illinois History, vol. 13, no. 3, 2010, pp. I89-210.

Schiller, Ben. "Learning Their Letters: Critical Literacy, Epistolary Culture, and Slavery in the Antebellum South." Southern Quarterly: A Journal of the Arts in the South, vol. 45, no. 3, 2008, pp. II-29.

Slater, Michael. Charles Dickens. Yale UP, 2009.

- Dickens: On America \& the Americans. U of Texas P, I978.

Stone, Harry. "Dickens' Use of His American Experiences in Martin Chuzzlewit." PMLA: Publications of the Modern Language Association of America, vol. 72, no. 3, I957, pp. 464-78.

Tillotson, Kathleen Mary. Novels of the Eighteen-Forties. Oxford UP, I954.

Tomalin, Claire. Charles Dickens: A Life. Penguin, $201 \mathrm{I}$.

Trollope, Fanny. Domestic Manners of the Americans. Penguin, 1997.

Twain, Mark, et al. Adventures of Huckleberry Finn. Oxford UP, I999.

Virgil. The Eclogues and The Georgics. Translated by C. Day Lewis. Oxford UP, I983.

Yablon, Nick. Untimely Ruins: An Archaeology of American Urban Modernity, I8I8-I9I9. $\mathrm{U}$ of Chicago P, 2010. 